Since the publication of my paper in 1895 , I have made a few observations of interest to which I may now refer. Crystals of saccharin which, when freshly prepared, flash brilliantly on crushing, gradually lose this property, and after a few weeks' preservation show no appreciable triboluminescence. Further, in order to obtain crystals which exhibit a brilliant triboluminescence, the impure commercial saccharin must be crystallised from acetone ; a carefully purified specimen of saccharin, when crystallised from acetone, yielded crystals which do not phosphoresce at all when broken. Both of these points are of great importance as affording possible clues to the cause of this strange property ; it would be of interest to ascertain whether the triboluminescence of cane sugar, hippuric acid, and other substances is in any way characteristic of the freshly prepared crystals, and is dependent on the presence of traces of impurity. Another point of great interest, indicating that triboluminescence is probably not a property of the chemical molecules, but only of the crystalline structure, is noted in Brugnatelli's paper; although the crystals of dextro-and lævo-ethylic santonite show brilliant triboluminescence, the anorthic crystals of the racemic compound of these two substances exhibit no triboluminescence.

In concluding this note on triboluminescence, may I point out that the study of the subject from a physical standpoint should be extremely fertile. Saccharin may now, thanks to commercial enterprise, be obtained in large quantities at a comparatively low cost.

William JaCkson POPE.

\section{EXPLOSIONS CAUSED BY COMMONLY OCCURRING SUBSTANCES.}

$T H E$ occurrence of a serious explosion in the Capitol at Washington, last November, has led the President of the American Society, Prof. C. E. Munroe, to address the members on the subject of explosions caused by commonly occurring substances. The address, which is fully reported in a recent number of Science, forms an interesting and valuable history of the subject, beginning with the well-known flour mills expiosion in Glasgow in 1872. A similar explosion in Minneapolis, in I878, shattered walls six feet thick at the base, and projected sheets of corrugated iron to a distance of more than two miles. The origin of the explosion was traced to the striking of fire by a pair of mill-stones through the stopping of the "feed." Dust explosions have also been recorded in connection with oatmeal, starch, rice, malt, spice, saw-dust, soap and zinc. In pharmacy and the arts accidents have arisen from various mixtures of combustible substances and oxidising agents in connection with matches, chlorate of potash lozenges, sodium peroxide and sodium bisulphite mixtures. Among substances explosive per se which have given rise to accidents, are erythryl nitrate, ammonium nitrate, and various nitroso compounds, diazo bodies, diamides, hydrazoic acid and its compounds, hydroxylamines, chlorates, carbonyl compounds, permanganates, peroxides, chlorides and iodides. Prof. Munroe devotes a considerable amount of space to explosions arising from the use and storage of petroleum, drawing his information mainly from English sources. He adds to the examples, well known in connection with British shipping, of explosions caused by the use of "driers" and paints made up with volatile hydrocarbons. A remarkable explosion occurred at Rochester, New York, in I 887, owing to the leakage of twelve thousand gallons of naphtha from a dislocated iron main into a sewer. The explosive mixture of air and vapour was ignited from a boiler fire through an untrapped watercloset, and the explosion, besides causing loss of life, destroyed three large mills. Prof. Munroe states that of substances supposed to impart safety to kerosene, alum and sal-ammoniac are practically insoluble in the liquid, and are of no effect ; whilst camphor, though it raises the flash-point, causes the vapour mixed with air to have a lower temperature of ignition.

After dealing with compressed gases and coal-dust explosions, Prof. Munroe reverts to the Washington explosion, and shows that it was due primarily to the escape of gas through a governor into a "live" 4 -inch main, owing to a sudden doubling of pressure. The gas found its way through a labyrinth of passages and compartments in a section of the building, and when the stratum of gas reached down to the level of some burning gas jets, ignition took place and the explosion was propagated in all directions, its intensity and range being increased by the disturbance of large accumulations of inflammable dust.

\section{TECHNICAL EDUCATION IN GERMANY.1}

$G$ ERMAN merchants and manufacturers are alive to the importance of increasing the efficiency of the mechanics and artisans, and of improving the quality of their goods. According to the United States Consul at Hanover, they appear to be resolved that "Made in Germany" shall no longer pass as a term of opprobrium, but be a synonym of excellent materials and good workmanship. A meeting took place recently in Hanover, which is likely to exercise a very important influence in this direction. It was in the nature of a conference, under Governmental sanction and direction, to discuss German trade and manufacturing interests, and to devise plans for their extension and improvement. It was held at the instance of the Prussian Minister of Trade and Commerce, and was presided over by the Oberregierungs President of the Province of Hanover, Count Stolberg. Representatives of the Government from Berlin, the highest officials of the Hanoverian provincial and municipal administrations, leading manufacturers and business men, delegates from the Chamber of Commerce, the manual training and artistic trade schools, and from the working men's trade unions, attended and took part in the deliberations. As a result of the conference, it was unanimously resolved: (I) To establish at once in the city of Hanover advanced lecture courses, in which artisans and apprentices in all trades shall have an opportunity to complete their mechanical education, and be instructed by experts how to install and manage a model workshop, and work and use machines and tools to the greatest advantage. Instruction will also be given in book-keeping, the making and rendering of accounts, the making of estimates of the cost of work and materials, how to conduct business correspondence, drawing, and other practical branches. (2) The supervision and control of the said lecture courses shall be under the direction of a commission composed of representatives from the Imperial. provincial, and municipal administrations, the Chamber of Commerce, the manual and art schools, and from the trade unions. (3) The first course of lectures will be for cabinetmakers, locksmiths, shoemakers and tailors. Those for other trades will follow. (4) A fee for tuition will be exacted from mechanics able to pay, but those unable to pay will be instructed free. Funds for the payment of the tuition of the poor will be provided by the Hanover provincial and municipal Governments. (5) Only mechanics and apprentices will be admitted to the classes whose theoretical and practical knowledge is such as to give promise of success as students. The Commission has power in all cases to decide as to qualification of applicants for admission. (6) Teachers are to be selected by the Commission, and confirmed by the Minister of Trade and Commerce. (7) The cost of the establishment and maintenance of the lectures is to be supplied by the General Government, and that of the province and city of Hanover, together with the trades unions, the Chamber of Commerce, and others interested therein. (8) It is further intended that great care shall be used in teaching apprentices how to obtain the most practical advantages from the knowledge obtained by them in the classes. To this end, the creation of working-men's co-operative societies is to be urged. (9) A permanent exhibition of all power machines and tools used in the small trades is to be established in the Gewerte Halle (Industrial Hall) in Hanover. The machines exhibited there are to be worked by competent mechanics, who, on request, will exhibit their uses and management to all inquirers. In connection with the machine exhibition, there will also be established an exhibition of sample products, in process of manufacture, as well as finished. (10) In order to enable small manufacturers and tradesmen to purchase their raw materials at wholesale prices, and to facilitate the sale of their products, the formation of co-operative stores is to be encouraged. Consul Anderson has been informed that the establishment of these courses of lectures to mechanics is the initial move in a general plan to be in all the main labour centres of Germany, dependent upon the success of this experiment.

\section{UNIVERSITY AND EDUCATIONAL INTELLIGENCE.}

OXFORD. - The following are the chief lectures advertised for the ensuing term in the Faculty of Natural Science, in addition to the elementary courses:-Prof. Gotch, on the nervous system; Dr. Mann, on histology of sense organs; Mr. Burch,

1 Reprinted from the Journal of the Society of Arts (April 14). 
on dioptrics of the eye; Prof. Weldon, on Tunicata; $\mathrm{Mr}$ Bourne, on the history of zoology ; Mr. Thompson, on mam. malian morphology; Prof. Sollas, on evolution of the earth and on palæontology ; Mr. Walden, on allotropy ; Prof. Miers, on isomorphism; Mr. Bowman, on rock-forming minerals ; Prof. Tylor, on anthropology in classical literature. Among the mathematical lectures are:-Prof. Love, on gravitational attraction and theory of potential ; Prof. Elliott, on theory of functions; Prof. Esson, on synthetic geometry of conics. Among the lectures in medicine are announced :-Prof. Thomson, on the urogenital system and anatomy of the placenta and embryonic membranes; Dr. Ritchie, on patho. logical bacteriology; Mr. Jerome, on medical pharmacology. The new Sedleian Professor of Natural Philosophy will also give an inaugural lecture on Thursday, April 27, on "The aims and methods of natural philosophy."

The recently appointed Wilde Reader in Mental Philosophy (Mr. G. F. Stout) will also deliver an inaugural lecture on Wednesday, April 26, on "Psychology as philosophy and as science."

An examination will be held on May 16 for the Abbott Scholarship, in the subjects of mechanics and physics, and chemistry. Candidates must be sons of clergymen of the Church of England, who stand in need of assistance.

CAMBRIDGE.- The honorary degree of Doctor of Science is to be conferred on Sir William Turner, Professor of Anatomy in the University of Edinburgh, and President of the General Medical Council ; and on the Rev. Thomas Wiltshire, Emeritus Professor of Geolngy in King's College, London. The ceremony will take place to-day (April 27). Mr. H. Jackson, First-class Natural Sciences Tripos I 896-98, has been elected a Fellow of Downing College.

THE appointments of the Earl of Kimberley to be Chancellor of the University of London, in the room of Lord Herschell, deceased; and of Mr. John Arthur Thomson to the chair of Natural History in the University of Aberdeen, in succession to the late Prof. Henry Alleyne Nicholson, are formally announced in the Gazette.

THE Board of Education Bill was read a second time in the House of Lords on Monday. Referring to the Bill, and in reply to criticisms, the Duke of Devonshire explained that the Government considered it desirable to reorganise the Education Department completely before the new local authorities for secondary education were called into existence. He knew of no insurmountable reason why a measure dealing with those local authorities should not be introduced and passed next Session. As regards the consultative committee, he remarked that the Government does not propose that it shall have any statutory character. The committee is to be the creation of the Minister, who is to be responsible for its action; and its duties are to be such as the Minister, on his responsibility, entrust to it.

THE following gifts to educational institutions in the United States are announced in Science: Mr. William K. Vanderbilt has given 100,000 dollars to Vanderbilt University for the erection of a new dormitory on the campus. - It is reported that the sum of over 250,000 dollars has been subscribed towards an endowment for Brown University. A committee is endeavouring to collect 2,000,000 dollars, which it is intended to devote to strengthening the departments already existing in the University. - A Bill has passed the Kansas Legislature granting 55,000 dollars for the erection of a new chemistry building at the State University.-Miss Catherine Wolfe Bruce has, through Prof. J. K. Rees, given I0,000 dollars to Columbia University, to be used for the measurement and discussion of astronomical photographs. Miss Bruce's gifts to the department of astronomy amount to 22, 100 dollars.

THE Technical Education Board of the London County Council will proceed shortly to award not fewer than five senior county scholarships which are of the value of $60 \%$ a year, together with payment of tuition fees up to $30 \%$. a year, and are tenable for three years at University colleges and advanced technical institutions. These scholarships are confined to residents within the Administrative County of London, and are open only to those whose parents are in receipt of not more than $400 l$. a year. Candidates should, as a rule, be under twenty-two years of age, though the Board reserves the right to give preference to candidates who are under nineteen years of

$$
\text { NO. I 539, voL. 59] }
$$

age. The scholarships are intended to enable those students who cannot afford a University training to pursue advanced studies for a period of three years in the highest University institutions in the country. Senior scholars appointed by the Board are studying at Cambridge, at colleges of University rank in London and elsewhere, and in University institutions on the continent. The Board usually makes a certain number of grants of lesser value in addition to awarding scholarships. Candidates must apply before Monday, May I5, to the Secretary of the Technical Education Board, I I6 St. Martin's Lane, W.C.

WITH reference to the paragraph which appeared in our last issue, in regard to the proposed foundation of a University for the West of England, we find that the suggestions of the Bishop of Hereford, the President of Bristol University College, appear to be receiving serious attention. The Bishop referred to the steps being taken in Birmingham so that Mason College may be incorporated as the University of Birmingham, and thus Birmingham become the home of a Midland University. $\mathrm{He}$ had come to the conclusion that within reasonable limits the multiplication of such University centres was a very real stimulus to the higher life of the community; and sometimes in his day-dreams he saw the time when they would have a University of Bristol, with the sister colleges, the University College and the Merchant Venturers' Technical College, spreading new life and intelligence not only throughout the vast community of the city, but to the West of England. In regard to this, $\mathrm{Mr}$. G. H. Pope, Secretary to the Merchant Venturers, writes to the local papers, and after hoping that the Bishop's dream may come true, adds that it is one "towards the ultimate fulfilment of which everything that the Merchant Venturers do for securing the completeness and perfection of their College is, not quite unconsciously, tending.'

A COPY of the Calendar of the School of Practical Science of the Province of Ontario, affiliated to the University of Toronto, has been received. There are five regular departments of instruction in the school, in each of which diplomas are granted, viz. :-Civil engineering (including sanitary engineering) ; mining engineering; mechanical and electrical engineering; architecture; analytical and applied chemistry. The regular course in each department is of three years' duration, and leads to the diploma of the school. Graduates electing to continue their studies for a fourth year are allowed to select two subjects from an approved list, and are required to confine their whole attention to these subjects during the fourth year. The subjects on this list are such as require a large amount of time to be devoted to laboratory and other practical work. During this year the student is required to prepare a thesis on some subject connected with his work. After complying with all requirements, the candidate receives from the University the degree of Bachelor of Applied Science (B.A.Sc.). Bachelors of Applied Science may, after three years spent in professional work, present themselves for the degrees of Civil Engineer (C.E.), Mining Engineer (M.E.), Mechanical Engineer (M.E.), or Electrical Engineer (E.E.), as the case may be, subject to the rules and regulations established by the University. Toronto thus gives the encouragement to engineering which $\mathrm{Mr}$. Stuart recently urged (see p. 524) should be more liberally given in our own Universities.

THE nineteenth annual report of the Council of the City and Guilds of London Institute, referring to the work of the Institute during the year 1898 , has just been issued. A letter sent to the London University Commission by the Institute, and published in the report, is of interest as it states the conditions under which the Institute is willing to accept the position of a School of the University for its Central Technical College. The conditions include the following:- "That, in addition to the Faculty of Science in the reconstituted University, a special separate Faculty of Engineering ought to be created to meet the needs of Schools of the University which are preparing students for a professional career. This Engineering Faculty should have direct representation on the Senate, and should include the subjects of civil engineering, mechanical engineering, electrical engineering, marine engineering, mining engineering, and might possibly also include chemical engineering, metallurgy, architectural construction, and sanitary engineering. The Institute is of opinion that as it appears undesirable, at all events in the first instance, to constitute unduly large faculties, each faculty should consist of the professors alone of the several schools included in the faculty." The Institute has been in- 
vited by the Education Sub-Committee of the Royal Commission for the Paris Exhibition of 1900 to co-operate in the work of securing for the exhibition an adequate and comprehensive representation of all grades of educational effort, public and private, in the United Kingdom, and Sir Owen Roberts has been appointed by the Executive Committee to attend the conferences convened by the Chairman, Sir George Kekewich, K.C.B., to consider the arrangements for the educational section.

\section{SCIENTIFIC SERIALS.}

American Journal of Science, April.-Glacial Lakes Newberry, Warren, and Dana in Central New York, by H. L. Fairchild. The ice sheet of the last glacial epoch covered all the area of the Great Lakes. When the receding front of the glacier had passed to northward of the southern boundary of the Laurentian basin, the glacial and meteoric waters were impounded between the ice front and the north-sloping land surface. These glacial lakes had their outlets southward across the divide, and they expanded northward as the barrier of ice receded. The author describes the succession of events in the life and extinction of the later and broader glacial waters in the critical district of the Finger Lakes. - Rapid method for the determination of the amount of soluble mineral matter in a soil, by T. H. Means. This method is an electrical one. The sample is treated with distilled water and the specific resistance of the solution is determined. Two men can thus examine from sixty to one hundred samples of soil in a day, and salt maps of irrigated and other districts may be rapidly constructed. - New type of telescope objective specially adapted for spectroscopic use, by C. S. Hastings. The author has constructed an objective consisting of a quadruple combination of silicate flint, borosilicate flint, silicate crown, and barium crown which is absolutely colour. free, and equally adapted to photographic and to eye observations. From the lines $A$ to $K$, the focal plane for all rays is rigidly the same. There are only two free surfaces, the four lenses being cemented together.- On the phenocrysts of intrusive igneous rocks, by L. V. Pirsson. Not all phenocrysts are intratelluric in the sense that they have been formed at much greater depths than they now occur in. On the contrary, in many cases they have been formed in place, and are of contem poraneous origin with the other constituents of the rocks. - The occurrence, origin, and chemical composition of chromite, by J. H. Pratt. The author has been led to adopt the theory that the chromite occurring in the peridotite rocks of North Carolina was formed at the same time as the peridotite, i.e. was held in solution by the molten mass of the peridotite and crystallised out among the first minerals as the mass began to cool.- Two species of Saurocephalus, by O. P. Hay. One of the species described, $S$. lanciformis, is little known. The other species is new. It has a slenderer head and a larger mouth than $S$. dentatus. The author names it $S$. pamphagus.

Correction. - The abstract of G. P. Starkweather's paper, $A m$. J. Sc. for February, should read: The writer adduces evidence from Regnault's own experiments to show that his calorimeter temperatures were reduced to the air thermometer, a fact questioned by Bosscha and others.

Symons's Monthly Meteorological Magazine, April.-Winter minima on British mountain tops. In 1867 , the late Mr. H. B. Biden placed a minimum thermometer on the Glyder fach, about four miles E.N.E. of Snowdon, at an altitude of 3262 feet. The thermometer was placed beneath a protecting slab of feldspar porphyry, and left to its fate, being read each spring, and then reset. Mr. W. Piffe Brown has discussed the temperatutes in the Climbers' Club Journal for February last. The average for the years $1884-96$ except 1894-95, when the record was lost) was $14^{\circ} \cdot 7$, the absolute minimum being $8^{\circ}$, in the winter of $1893-94$. The accumulation of snow may account for the readings not being lower, but it is improbable that there was always snow there at times of severe cold. At Ben Nevis, the average of the minima for the same period is $7^{\circ} \cdot 5$, the absolute minimum being $0^{\circ} \cdot 7$ in January 1894 . A very contradictory record was obtained by the late Dr. J. F. Miller at Scaw Fell, where the wonderful temperature of $-3 \mathrm{I}^{\circ}$ was recorded for January and February 1850.-Negretti and Zambra's self-recording rain gauge. Mr. Symons states that this is a very simple and efficient instrument; the rain collected by the receiver falls into the upper half of the vibrating bucket (designed by Sir Christopher Wren). When O.I inch of rain has fallen, the bucket tips over and causes a wheel to advance one tooth. Attached to the wheel is a helix on which rests the lever carrying the pen which registers each turnover of the bucket. As the clock (the useful invention of MM. Richard frères) turns the paper about ${ }^{\circ} \mathrm{OoI}$ inch per minute, a very clear curve is produced. The approval of the instrument by $\mathrm{Mr}$. Symons is a guarantee of its usefuiness, and the cost is much below some other recording gauges.

THE Fournal of the Royal Microscopical Society for April contains the President's annual address, which is chiefly devoted to the subject of dispersion; the description of a microscope with new focussing mechanism, by Mr. Keith Lucas; and notes on colour-illumination, with special reference to the choice of suitable colours, by Mr. Julius Rheinberg. Among the notes on microscopy is a contribution to the President's interesting article on the evolution of the microscope, and a description of Powell's iron microscope made in $1838-40$ In the same number is a table of the conversion of British and metric measures, computed by Mr. E. M. Nelson from the new coefficient obtained by order of the Board of Trade in 1896.

Wiedemann's Annalen der Physik und Chemie, No. 3.-Behaviour of unpolarisable electrodes towards alternate currents, by $\mathrm{E}$. Warburg. If polarisation is altogether due to the solution of the electrode metal in the liquid and its attendant changes of concentration, the "capacity of polarisation" must be inversely proportional to the square root of the frequency. This applies to the case of silver electrodes in silver nitrate solution, and, to a certain extent, to platinised platinum electrodes in saturated $\mathrm{NaCl}$ solution.-Methods of studying slow electric oscillations, by W. König. The author describes several new methods of recording and studying electric oscillations of a frequency comparable with that of ordinary sound-waves. One of these consists in discharging them through a rod provided with a short piece of straw at the end on to a metallic plate covered with asphalt varnish. The sparks produce on the plate something resembling Lichtenberg's figures. The plate is attached to a pendulum, and is drawn across the point. On sprinkling the plate with a mixture of sulphur and red lead a series of red and yellow patches appears, which in connection with the known speed of the pendulum gives the frequency of the sparks. The straw may also be attached to the vibrating prong of a tuning-fork, and so a more direct measurement obtained. The straw is necessary to reduce the intensity of the spark, so as to obtain a sharp line.-A new method of exhibiting electric wire waves, by W. D. Coolidge. The author obtains a glow of the wires of a Lecher wire system at the ventral segments of the stationary waves in the open air by using a Blondlot exciter worked with an induction coil and Tesla transformer, and reducing the thickness of the wire to $0.1 \mathrm{~mm}$.- Alternate-current energy consumed in vacuum tubes, by If. Ebert. Very high frequencies were employed, such as 22,000 oscillations per minute. It was found that at a certain high exhaustion the consumption of energy for a given luminous effect attained a minimum. The pressure at which this takes place is inversely proportional to the mean free path of the gaseous molecules.Absolute determination of thermal radiation by means of the electric compensating pyrheliometer, by $\mathrm{K}$. Ångström. Of two equal blackened strips of metal, one is exposed to the radiation while the other is brought to the same temperature by means of an electric current. The latter furnishes a measure of the radiation. - Measurement of flame temperatures by means of thermo-couples, by F. Berkenbusch. Two new methods devised by Nernst are tested. - Pressure of saturated water vapour below $0^{\circ}$, by M. Thiesen. The author calculates the vapour pressures over ice and over water respectively down to $-80^{\circ}$.

\section{SOCIETIES AND ACADEMIES. LONDON.}

Physical Society, April 2I.-Mr. T. H. Blakesley, VicePresident, in the chair.-A mathematical paper on the effect of a solid conducting sphere in a variable magnetic field on the magnetic induction at a point outside, was read by Mr. C. S. Whitehead. It is an investigation of the magnetic induction at a point outside a solid conducting sphere when magnetic dis- 